\title{
Melanoides tuberculata AS INTERMEDIATE HOST OF Philophthalmus gralli IN BRAZIL
}

\author{
Hudson Alves PINTO \& Alan Lane de MELO
}

\begin{abstract}
SUMMARY
Melanoides tuberculata that naturally harbored trematode larvae were collected at the Pampulha dam, Belo Horizonte (Minas Gerais, Brazil), during malacological surveys conducted from 2006 to 2010 . From 7,164 specimens of M. tuberculata collected, 25 $(0.35 \%)$ were infected by cercariae, which have been morphologically characterized as belonging to the Megalurous group, genus Philophthalmus. Excysted metacercariae were used for successful experimental infection of Gallus gallus domesticus, and adult parasites recovered from the nictitating membranes of chickens were identified as Philophthalmus gralli. This is the first report of $P$. gralli in M. tuberculata in Brazil.
\end{abstract}

KEYWORDS: Philophthalmus gralli; Melanoides tuberculata; Eyefluke; Brazil; Snail intermediate host.

\section{INTRODUCTION}

Melanoides tuberculata (Müller, 1774), an exotic species of snail introduced in Brazil in the late $1960 \mathrm{~s}^{35}$, has been found in several Brazilian states ${ }^{9}$. Studies related to the interaction between M. tuberculata and some species of Biomphalaria Preston, 1910, which transmit Schistosoma mansoni Sambon, 1907 in the country have reported that endemic populations of planorbids coexists with these thiarids despite their displacement ${ }^{12,13,32}$. Other studies did not confirm the coexistence of planorbids with thiarids, but verified the significant decline or complete disappearance of Biomphalaria species after the introduction of thiarids ${ }^{14,15}$. However, the possible use of $M$. tuberculata as a biological control strategy against schistosomiasis must be considered with caution because of possible damage to the native fauna (as an alien species), and the potential of $M$. tuberculata to act as an intermediate host for parasites of medical and veterinary importance in Brazil are not fully understood. Some studies have already reported the finding of $M$. tuberculata that harbor Pleurolophocercous cercariae in Brazil ${ }^{4,5,33}$. Recently this cercarian type found in $M$. tuberculata from the state of Minas Gerais was identified as Centrocestus formosanus (Nishigori, 1924) $)^{28}$.

The aim of this study is to report the natural infection of $M$. tuberculata by another type of trematode larvae in Brazil, cercariae of Philophthalmus Looss, 1899, which have been used for experimental life cycle studies allowing the morphological identification of the oriental eyefluke P. gralli Mathis and Leger, 1910.

\section{MATERIALS AND METHODS}

Mollusks were collected during 26 random malacological surveys (over minimum intervals of one month), conducted from 2006 to 2010 at Pampulha dam, an eutrophic artificial water body with an area of 260 hectares and a total water volume of 12 million $\mathrm{m}^{3}$ located in the northern region of the city of Belo Horizonte, in the state of Minas Gerais, Brazil. The mollusks were obtained with a scoop net and long forceps, and were packed and transported to the laboratory, then placed individually in plastic receptacles containing $5 \mathrm{~mL}$ of tap water and left overnight at room temperature. The thiarids were examined with a stereomicroscope before and after artificial photostimulation. Emerged cercariae were studied under a light microscope with vital stains while alive $(0.05 \%$ neutral red, $0.05 \%$ Nile blue, $0.05 \%$ alizarin red), or after being fixed in $10 \%$ formalin, stained with acetic carmine, cleared in beechwood creosote and mounted in Canada balsam, according to MELO (2008) ${ }^{22}$. To study intramolluscan parasitic stages, naturally infected snails were crushed between two glass plates and dissected under a stereoscopic microscope; the larvae found were collected and studied alive.

Young specimens of Gallus gallus domesticus (Linnaeus, 1758) $(\mathrm{n}=5)$ were orally administered with twenty mechanically excysted metacercariae each. The chickens were sacrificed and necropsied at four weeks after infection, according to the local animal experimentation ethics committee (CETEA/UFMG). Ovigerous flukes were recovered from the nictitating membranes and conjunctival sacs of the chickens and were pressed between glass slides, fixed in cold $10 \%$ formalin and stained and mounted as described above.

Measurements of the developmental stages obtained were performed with a millimetered eyepiece. Ten larvae specimens and 13 adult parasites were measured. Drawings were made in camera lucida and photographic documentation was performed with a digital camera attached to a light microscope. The cercariae were identified and characterized according to

Laboratório de Taxonomia e Biologia de Invertebrados, Departamento de Parasitologia, Instituto de Ciências Biológicas, UFMG. Belo Horizonte, MG, Brasil.

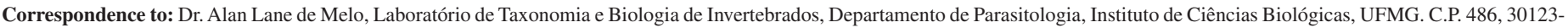
970 Belo Horizonte, Minas Gerais, Brasil. E-mail: aldemelo@icb.ufmg.br 
previously published descriptions ${ }^{7,10,30,31,34}$. Adult parasites were identified with the aid of taxonomical keys and the earlier descriptions of several authors $1,6,8,11,19,21,24,25,29$. Measurements are given in micrometers $(\mu \mathrm{m})$.

The specimens studied were deposited in the collection of the Department of Parasitology (DPIC), UFMG, under accession number 5926 a-m; e 5927.

\section{RESULTS}

In all, 7,164 specimens of M. tuberculata were collected and examined. A different type of cercaria emerged from $25 \mathrm{M}$. tuberculata specimens $(0.35 \%)$ which was preliminarily characterized as belonging to the Megalurous group (Fig. 1a). Larvae tended to emerge during the morning, in small numbers, and were very active. They presented elongated body measurements of, on average, 535 (420-580) long by 128 (110-140) wide with a constriction at the level of the ventral sucker. The subterminal oral sucker is 58 (50-69) long by 55(49-65) wide and followed by a long prepharynx, a muscular pharynx and an esophagus bifurcating into two blind caeca that reach the posterior end of the body. The ventral sucker was equatorial, with a circumference averaging 68 (65-78) long by 75 (60-80) wide. The genital primordium was formed by two longitudinal cell masses dorsal to the ventral sucker. Numerous cystogenous cells were observed. The tail was simple and slender, averaging 434 (302-485) long by 54 (36-62) wide, with adhesive glands at the terminal region. These cercariae encysted rapidly at the bottom of the receptacle or on the shell of the mollusks. Metacercariae usually had a typical pyriform shape averaging 315 (300-380) long by 210 (184236) wide (Fig. 1b).

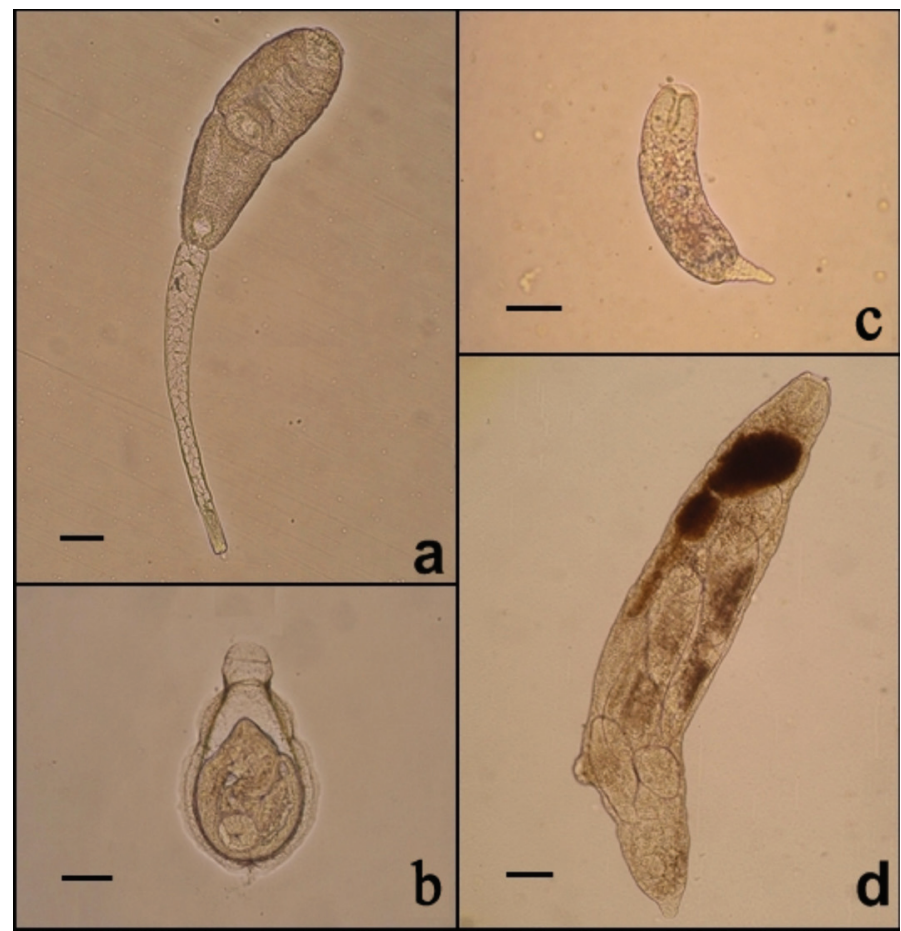

Fig. 1 - Developmental stages of Philophthalmus gralli obtained from naturally infected Melanoides tuberculata in Brazil. Cercaria (a), metacercaria (b), young redia (c) and adult redia (d). Scale bars $=100 \mu \mathrm{m}$.
During the dissection of naturally infected snails, mature and young rediae were found. Young rediae (Fig. 1c) were characterized by an elongated body that averaged 375 (334-457) long by 78 (68-96) wide and a muscular pharynx that averaged 53 (48-63) long by 45 (38-53) wide, with a tail-like process at the posterior end of the body. Mature rediae (Fig. 1d) were characterized by a sac-like elongated body that averaged 946 (653-1,203) long by 178 (155-206) wide. A muscular pharynx measured 73 (63-88) long by 74 (57-75) wide. Dark-colored intestinal caecum that were on average 397 (273-512) long by 50 (27-68) wide, extended up the half of the body. The birth pore was located on the anterior body, below the level of the pharynx. A pair of appendages and tail-like structures was present at the posterior region. Germ balls and cercariae were observed at different developmental stages. The morphological and biological characteristics of these larvae and of the intramolluscan stages make it possible to identify these Megalurous cercariae as belonging to the trematodes of the genus Philophthalmus.

In the experimental infection, 23 adult parasites were obtained from the nictitating membranes and conjunctival sacs (Fig. 2a) of all of the chickens, with a mean intensity of infection 7 (2-12) parasites. The recovered specimens (Fig. 2d) have an elongated body, that is an average of $3,610(3,100-4,070)$ long by $1,020(860-1,210)$ wide. The oral sucker subterminal is, on average, 330 (316-339) long by 401 (374-421) wide. The prepharynx is very small or absent. The muscular pharynx is located posterior to the oral sucker, and is on average 299 (279-316) long by 339 (326-358) wide. The ratio of the transverse diameter of the oral sucker to that of the pharynx is $1: 0.5-1.05(1: 0.86)$. The esophagus is small, bifurcating at the border of the ventral sucker. The ventral sucker (acetabulum) is located on the anterior third of body and is an average of

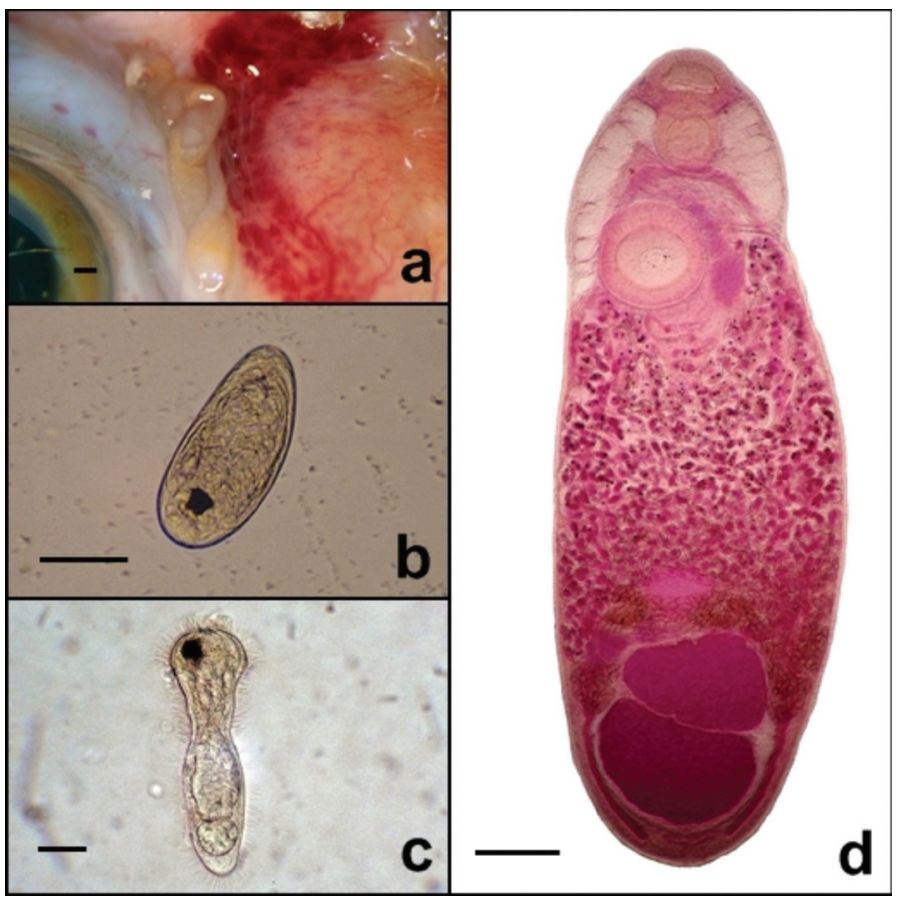

Fig. 2 - Developmental stages of Philophthalmus gralli obtained from chickens experimentally infected with larvae emerged from naturally infected Melanoides tuberculata from Brazil. These photos feature parasites in the conjunctival sac of a chicken (a), a mature egg (b), a miracidium (c), an adult parasite (d). Scale bars $=50 \mu \mathrm{m}$ (b, c); $500 \mu \mathrm{m}$ (a, d). 
514 (479-542) long by 514 (479-542) wide. The ratio of the transverse diameter of the oral sucker to that of the acetabulum is $1: 1.22(1: 1.5)$. The cirrus pouch is elongated, averaging 758 (507-1,000) by 120 (86$464)$, with a seminal vesicle extending posteriorly to the ventral sucker. The testes are oval and are situated in tandem; the testes are located at the position post ovarian, intercecal, in the posterior part of body. The anterior testis measures, on average, 222 (179-263) long by 403 (279453 ) wide. Posterior testis measures, on average, 216 (174-247) long by 351 (268-421) wide. The shape of the ovary varied from round to oval, and is situated medially in a pretesticular and post-uterine position. The ovary measures 237 (211-258) long by 266 (245-300) wide. The genital pore is medially located at the esophageal bifurcation. The location of the uterus is post-acetabular, pretesticular and intercecal (presenting mature eggs that contained miracidia with eyespots). The vitellaria are bilateral, extracecal, tubular, and extended 87\% (73-97\%) of the distance from the anterior testis to the ventral sucker. Mature eggs (Fig. 2b) are non-operculated and are located at the distal uterine coils. The mature eggs were an average size of 135 (120-145) long by 61 (53-65) when fresh and 73 (60-87) by 32 (27-36) after staining. The miracidium (Fig. $2 c$ ) is an average size of 131 (92-171) long by 53 (38-62) wide, and had a preformed redia stage. The main excretory ducts extended up the anterior part of the body. The excretory pore is terminal.

The morphometric data related to adult parasites obtained experimentally in the present study were compared with other neotropical records of Philophthalmus and the results are presented in the Table 1, represented as the amplitude followed by the mean in brackets (in micrometers) when available. The morphological and

Table 1

Measurements of Philophthalmus gralli obtained from chickens that were experimentally infected with trematodes larvae emerged from Melanoides tuberculata in Brazil, and compared with South American records of Philophthalmus. Morphometric data in micrometers are presented as amplitude followed by the mean in brackets.

\begin{tabular}{|c|c|c|c|c|c|c|c|}
\hline & & & Philophthalmus gralli & & Philophthalm & lachrymosus & Philophthalmus \\
\hline & & Present study & $\begin{array}{l}\text { Muniz-Pereira and } \\
\text { Amato, } 1993\end{array}$ & Díaz et al., 2002 & Freitas, 1955 & Pinto et al., 2005 & Nasir and Díaz, 1972 \\
\hline Locality & & Belo Horizonte, & Maricá, & $\begin{array}{l}\text { Aguasanta and } \\
\text { Yaguaracal }\end{array}$ & Manguinhos, & Foz do Iguaçu, & Laguna del Peñon \\
\hline & & MG, Brazil & RJ, Brazil & Venezuela & RJ, Brazil & PR, Brazil & Venezuela \\
\hline Host & & Gallus gallus & Anas bahamensis & Gallus gallus & Casmerodius albus & Hydrochaeris & Catoptrophorus \\
\hline & & domesticus & $\begin{array}{l}\text { Amazoneta } \\
\text { brasiliensis }\end{array}$ & domesticus & & hydrochaeris & semipalmatus \\
\hline $\mathrm{n}$ & & 13 & 9 & 25 & 6 & 10 & - \\
\hline Body & $\mathrm{L}$ & $3100-4070(3610)$ & $2120-3710(2710)$ & $2564-3384$ & $4190-4620$ & $3400-4250(3730)$ & $2624-4475$ \\
\hline & W & $860-1210(1020)$ & $604-1280(834)$ & $512-1205$ & $1380-1640$ & $850-1530(1080)$ & $960-1794$ \\
\hline Oral sucker & $\mathrm{L}$ & $316-339(330)$ & $204-329(260)$ & $237-297$ & $300-310$ & $220-290(260)$ & $216-363$ \\
\hline & W & $374-421(401)$ & $277-421(332)$ & $287-378$ & $360-430$ & $260-330(300)$ & $253-485$ \\
\hline Ventral sucker & $\mathrm{L}$ & $479-542(514)$ & $343-549(418)$ & $388-544$ & $610-690$ & $610-720(670)$ & 917 \\
\hline & W & $479-542(514)$ & 343-494 (391) & $409-505$ & - & $630-770(700)$ & 958 \\
\hline OS/VS & & $1-1,22$ & $1-1,1-1,3$ & $1-1,3$ & $1-2$ & $1-2$ & $1-2,75$ \\
\hline Pharynx & $\mathrm{L}$ & 279-316 (299) & $183-293(226)$ & $227-323$ & $310-350$ & $190-210(200)$ & $225-333 d$ \\
\hline & $\mathrm{W}$ & $326-358$ (339) & $183-403(277)$ & $227-333$ & $380-460$ & $90-150(110)$ & - \\
\hline Ovary & $\mathrm{L}$ & $211-258(237)$ & $88-219(153)$ & $126-222$ & $200-210$ & $150-280(190)$ & $188-394 d$ \\
\hline & $\mathrm{W}$ & $245-300(266)$ & $88-256(181)$ & $151-252$ & $180-220$ & $150-290(210)$ & - \\
\hline Anterior testis & $\mathrm{L}$ & $179-263(222)$ & $161-416(258)$ & $272-378$ & $360-480$ & $140-270(230)$ & $188-297$ \\
\hline & W & $279-453(403)$ & $234-445$ (329) & $424-530$ & $460-550$ & $280-460(370)$ & $206-563$ \\
\hline Posterior testis & $\mathrm{L}$ & $174-247(216)$ & $161-438(248)$ & $272-464$ & $380-480$ & $150-360(280)$ & $188-454$ \\
\hline & $\mathrm{W}$ & $268-421(351)$ & 241-504 (319) & 404-505 & $450-530$ & $280-470(360)$ & $216-669$ \\
\hline Eggs & $\mathrm{L}$ & $60-87$ (73) & $64-90(70)$ & $74-80$ & $94-97$ & $90-110(100)$ & $60-69$ \\
\hline & W & $27-36(32)$ & $22-40(33)$ & $25-35$ & $38-42$ & $21-40(30)$ & $18-30$ \\
\hline Type of vitellaria & & tubular & tubular & tubular & follicular & follicular & follicular \\
\hline Extension of vitellaria & $\%$ & $73-97(87)$ & $79-89$ & - & - & $71-90(78.6)$ & - \\
\hline
\end{tabular}

$\mathrm{d}=$ diameter $\mathrm{L}=$ length; $\mathrm{W}=$ width 
biological characteristics of the parasite reported here made possible the identification of the eyefluke Philophthalmus gralli Mathis and Leger, 1910 .

\section{DISCUSSION}

Most of trematodes of the family Philophthalmidae Looss, 1899 are cosmopolitan eyeflukes of birds and mammals, and have already been reported to infect human beings ${ }^{20,26}$. In Brazil, two species of Philophthalmus have been reported only in vertebrate hosts. Philophthalmus lachrymosus Braun, 1902 was described in Rio de Janeiro (RJ, Brazil) in the brown-hooded gull, Larus maculipennis (Lichtenstein, 1823). The species has also been found in the great egret, Casmerodius albus egretta (Gmelin, 1789) from the same state ${ }^{11}$, as well as the capybara, Hydrochaeris hydrochaeris Linnaeus, 1766 in Foz do Iguaçu (PR, Brazil) ${ }^{29}$. Another species, Philophthalmus gralli Mathis and Leger, 1910 was initially described in Gallus from Asia, and has also been registered in the white-cheeked pintail, Anas bahamensis Linnaeus, 1758 and in the Brazilian teal, Amazonetta brasiliensis Boetticher, 1929 in Maricá (RJ, Brazil) ${ }^{24}$. More recently, P. gralli have been found in ostriches, Struthio camelus Linnaeus, 1758 in Caratinga (MG, Brazil) ${ }^{36}$. Despite these reports, mollusks naturally infected by Philophthalmus have still not been reported in Brazil.

Originally described in G. gallus domesticus in Vietnam, the biological cycle of $P$. gralli has primarily been elucidated in North America, where the developmental stages and the participation of thiarids mollusks in its transmission have been described ${ }^{1,2,3,6,37}$. Since then, several studies have confirmed the participation of $M$. tuberculata as an intermediate host of $P$. gralli in different countries, such as the $\mathrm{USA}^{27}, \mathrm{Jordan}^{17,18}, \mathrm{Mexico}^{31}$, the United Arab Emirates ${ }^{16}$, Saudi Arabia ${ }^{19}$, Venezuela ${ }^{8}$ and Zimbabwe ${ }^{23}$. The biological and morphological characteristics of $P$. gralli reported here are in accordance with those described by these authors, differing from P. lachrymosus and P. semipalmatus (Nasir and Díaz, 1972) mainly by their smaller ventral sucker, the type (tubular), and the longer length of vitellaria.

In Brazil, the possible involvement of M. tuberculata in the transmission of Philophthalmus has been suggested ${ }^{24,29,36}$, however, its occurrence has not been previously verified in nature. In the present study, the participation of $M$. tuberculata in the biological cycle of $P$. gralli in Brazil is confirmed, but the natural definitive host of $P$. gralli in Pampulha dam remains unknown. Given that $M$. tuberculata is widespread in Brazil and participates in the life cycle of Philophthalmus in the country, the impact of introducing and spreading these thiarids around the country must be better evaluated, with an aim toward preventing future cases of philophthalmiasis.

\section{RESUMO}

\section{Melanoides tuberculata como hospedeiro intermediário de Philophthalmus gralli no Brasil}

Melanoides tuberculata naturalmente infectados por larvas de trematódeos foram coletados na represa da Pampulha Belo Horizonte, Minas Gerais, Brasil durante estudos malacológicos realizados entre 2006 e 2010. De 7164 exemplares de M. tuberculata coletados, 25 (0,35\%) apresentavam-se infectados por cercárias que foram caracterizadas morfologicamente como pertencentes ao grupo Megalura, gênero Philophthalmus. Metacercárias desencistadas foram utilizadas com sucesso para a infecção experimental de Gallus gallus domesticus e parasitos adultos recuperados da membrana nictitante das aves foram identificados como Philophthalmus gralli. Este é o primeiro relato de $P$. gralli em M. tuberculata no Brasil.

\section{ACKNOWLEDGMENTS}

To Mr Airton Lobo for technical assistance and to Conselho Nacional de Desenvolvimento Científico e Tecnológico (CNPq) for financial support and scholarship to Hudson Alves Pinto.

\section{REFERENCES}

1. Alicata JE. Life cycle and developmental stages of Philophthalmus gralli in the intermediate and final hosts. J Parasitol. 1962;48:47-54.

2. Alicata JE, Ching HL. On the infection of birds and mammals with cercariae and metacercariae of the eye-fluke Philophthalmus. J Parasitol. 1960;46:16.

3. Alicata JE, Noda K. The life history of a species of Philophthalmus, an eye-fluke of birds in the Hawaiian Islands. J Parasitol. 1959;45(Suppl):22.

4. Boaventura MF, Fernandez MA, Thiengo SC, Silva RE, Melo AL. Formas larvais de Trematoda provenientes de gastrópodes límnicos da microrregião Rio de Janeiro, sudeste do Brasil. Lundiana. 2002;3:45-9.

5. Bogéa T, Cordeiro FM, Gouveia JS. Melanoides tuberculatus (Gastropoda: Thiaridae) as intermediate host of Heterophyidae (Trematoda: Digenea) in Rio de Janeiro metropolitan area, Brazil. Rev Inst Med Trop Sao Paulo. 2005;47:87-90.

6. Ching HL. The development and morphological variation of Philophthalmus gralli Mathis and Leger, 1910 with a comparison of species of Philophthalmus Looss, 1899. Proc Helm Soc Wash. 1961;28:130-8.

7. Cort WW. Larval trematodes from North American fresh-water snails. J Parasitol. 1914;1:65-84.

8. Díaz MT, Hernández LE, Bashirullah AK. Experimental life cycle of Philophthalmus gralli (Trematoda: Philophthalmidae) in Venezuela. Rev Biol Trop. 2002;50:629-41.

9. Fernandez MA, Thiengo SC, Simone LRL. Distribution of the introduced freshwater snail Melanoides tuberculatus (Mollusca; Thiaridae) in Brazil. Nautilus. 2003;117:78-82.

10. Fisher FM, West AF. Cercaria megalura Cort, 1914, the larva of a species of Philophthalmus. J Parasitol. 1958;44:648.

11. Freitas JFT. Sobre dois trematódeos parasitos de aves: Philophthalmus lachrymosus Braun, 1902 e Renicola mirandaribeiroi n. sp. Arq Mus Nac. 1955;42:585-610.

12. Freitas JR, Santos MBL. Current advances on the study of snail-snail interactions, with special emphasis on competition process. Mem Inst Oswaldo Cruz. 1995;90:261-9.

13. Giovanelli A, Silva CLPAC, Leal GBE, Baptista DF. Habitat preference of freshwater snails in relation to environmental factors and the presence of the competitor snail Melanoides tuberculatus (Müller, 1774). Mem Inst Oswaldo Cruz. 2005;100:169-76.

14. Giovanelli A, Vieira MV, Silva CLPAC. Interaction between the intermediate host of schistosomiasis in Brazil, Biomphalaria glabrata (Say, 1818) and a possible competitor, Melanoides tuberculata (Müller, 1774): a field study. J Mollus Stud. 2005;71:7-13.

15. Guimarães CT, Souza CP, Soares DM. Possible competitive displacement of planorbids by Melanoides tuberculatus in Minas Gerais, Brazil. Mem Inst Oswaldo Cruz. 2001;96 (Suppl):173-6. 
16. Ismail NS, Arif AMS. Occurrence of Philophthalmus gralli Mathis and Leger, 1910 (Trematoda: Philophthalmidae) in a desert spring of the United Arab Emirates. Jpn J Parasitol. 1992;41:261-5.

17. Ismail NS, Issa I. Life cycle of Philophthalmus gralli (Trematoda: Philophthalmidae) in Azraq Oasis, Jordan. Jpn J Parasitol. 1987;36:53-62.

18. Ismail NS, Saliba EK. Studies on larval stages of digenetic trematodes of Melanoides tuberculata (Muller) snails from Azraq oasis, Jordan. Riv Parassitol. 1985;46:263-71.

19. Kalantan AMN, Arfin M, Al-Arefi HA, Bobshait HI, Hamadah SA, Al-Thawab FH, et al. Occurrence of larval Philophthalmus gralli (Mathis and Leger, 1910) in freshwater snail, Melanoides tuberculatus (Muller) from Al-Hafuf, Saudi Arabia and its development into adult in various experimental hosts. Parasitol Int. 1997;46:127-36.

20. Kanev I, Nollen PM, Vassilev I, Dimitrov V. Redescription of Philophthalmus lucipetus (Rudolphi, 1819) (Trematoda: Philophthalmidae) with a discussion of its identity and characteristics. Ann Nat Mus Wien. 1993;94/95B:11-34.

21. Kanev I, Radev V, Fried B. Family Philophthalmidae Looss, 1899. In: Jones A, Bray R, Gibson D, editors. Keys to the Trematoda. Wallingford: CABI International; 2005. v. 2, p. 87-97.

22. Melo AL. Caracterização de larvas de trematódeos emergentes de moluscos dulciaquícolas. In: Amaral RS, Thiengo SC, Pieri OS, organizadores. Vigilância e controle de moluscos de importância epidemiológica: diretrizes técnicas: Programa de Vigilância e Controle da Esquistossomose (PCE). 2. ed. Brasília: Ministério da Saúde; 2008. p. 71-80.

23. Mukaratirwa S, Hove T, Cindzi ZM, Maononga DB, Taruvinga M, Matenga E. First report of a field outbreak of the oriental eye-fluke, Philophthalmus gralli (Mathis \& Leger 1910), in commercially reared ostriches (Struthio camelus) in Zimbabwe. Onderstepoort J Vet Res. 2005;72:203-6.

24. Muniz-Pereira LC, Amato SB. Philophthalmus gralli (Digenea: Philophthalmidae) parasite of Anas bahamensis and Amazonetta brasiliensis, from lagoons of Maricá county, Rio de Janeiro, Brazil. Mem Inst Oswaldo Cruz. 1993;88:567-9.

25. Nasir P, Díaz MT. Avian flukes of Venezuela. Riv Parassitol. 1972;33:245-76.

26. Nollen PM, Kanev I. The taxonomy and biology of philophthalmid eyeflukes. Adv Parasitol. 1995;36:205-69.

27. Nollen PM, Murray HD. Philophthalmus gralli: identification, growth characteristics, and treatment of an oriental eyefluke of birds introduced into the continental United States. J Parasitol. 1978;64:178-80.
28. Pinto HA, Melo AL. Melanoides tuberculata (Mollusca: Thiaridae) as an intermediate host of Centrocestus formosanus (Trematoda: Heterophyidae) in Brazil. Rev Inst Med Trop Sao Paulo. 2010;52:207-10.

29. Pinto RM, Santos LC, Tortelly R, Menezes RC, Moraes W, Juvenal JC, et al. Pathology and first report of natural infections of the eye trematode Philophthalmus lachrymosus Braun, 1902 (Digenea, Philophthalmidae) in a non-human mammalian host. Mem Inst Oswaldo Cruz. 2005;100:579-83.

30. Radev V, Kanev I, Gold D. Life cycle and identification of an eyefluke from Israe transmitted by Melanoides tuberculata (Müller, 1774). J Parasitol. 2000;86:773-6.

31. Scholz T, Aguirre-Macedo ML, Diaz de Leon ATSF, Ditrich O. Larval stages of trematodes in Mexican freshwater mollusc: a review of present state and methodology for future research. In: Salgado-Maldonado G, García-Aldrete AN, Vidal-Martínez VM, editors Metazoan parasites in the neotropic: a systematic and ecological perspective. México: Instituto de Biología, Universidad Nacional Autónoma de México; 2000. p. 77-100.

32. Silva RE, Melo AL, Pereira LH, Frederico LF. Levantamento malacológico da bacia hidrográfica do lago Soledade, Ouro Branco (Minas Gerais, Brasil). Rev Inst Med Trop Sao Paulo. 1994;36:437-44

33. Thiengo SC, Fernandez MA, Boaventura MF, Grault CE, Silva HFR, Mattos AC, et al. Freshwater snails and schistosomiasis mansoni in the state of Rio de Janeiro, Brazil: I - Metropolitan Mesoregion. Mem Inst Oswaldo Cruz. 2001; 96(Suppl):177-84.

34. Urabe M. Cercariae of a species of Philophthalmus detected in a freshwater snail, Semisulcospira libertina, in Japan. Parasitol Int. 2005;54:55-7.

35. Vaz JF, Teles HMS, Correa MA, Leite SPS. Ocorrência no Brasil de Thiara (Melanoides) tuberculata (O. F. Müller, 1774) (Gastropoda, Prosobranchia), primeiro hospedeiro intermediário de Clonorchis sinensis. Rev Saúde Pública. 1986;20:318-22.

36. Verocai GG, Lopes LN, Burlini L, Correia TR, Souza CP, Coumendouros K. Occurrence of Philophthalmus gralli (Trematoda: Philophthalmidae) in farmed ostriches in Brazil. Trop Anim Health Prod. 2009;41:1241-2.

37. West AF. Studies on the biology of Philophthalmus gralli Mathis and Leger 1910 (Trematoda: Digenea). Am Midl Nat. 1961;66:363-83.

Received: 26 July 2010

Accepted: 6 October 2010 